\title{
In Between the 'Brows': The Influx of Highbrow Literature into Popular Music
}

\begin{abstract}
The global phenomenon of popular music from the middle of the twentieth century on played a pivotal role in the merging of what was traditionally deemed high and low cultures. Performers of popular music of different genres started including direct references to literary works from the Anglo-American literary canon, one of the most famous examples being Kate Bush's 1989 single "The Sensual World," in which she originally intended to quote verbatim from Molly Bloom's soliloquy Bloom in James Joyce's Ulysses; however, since permission from the Joyce Estate was not granted, the song did get recorded, but with lyrics that Bush wrote herself, inspired by Molly Bloom's words on the page.

This paper analyses the way ideas from the original literary work get transposed and adapted in the lyrics of the popular song, giving credit to the musicians as not only innovative creators of a new work of art, but creators of an adapted work of art that can be intertextually read in the context of the artist's cultural heritage.
\end{abstract}

Keywords: popular culture; rock music; literature; adaptation

\section{Med visoko in nizko kulturo: Vdor visoke književnosti $v$ popularno glasbo}

POVZETEK

Popularna glasba, kot globalni fenomen, igra od sredine dvajsetega stoletja dalje ključno vlogo pri združevanju elementov, ki po tradicionalni delitvi veljajo za visoko in nizko kulturo. Izvajalci popularne glasbe različnih žanrov so $\mathrm{v}$ besedila svojih pesmi vključevali neposredne reference na književna dela iz anglo-ameriškega kanona. Eden najbolj znanih primerov je single "The Sensual World" pevke in avtorice Kate Bush iz leta 1989. Pesem naj bi prvotno vsebovala dobeseden citat samogovora Molly Bloom iz Joyceovega Uliksesa, vendar se pisateljevi dediči s tem niso strinjali. Tako je besedilo, za katerega je dobila navdih v besedah Molly Bloom, napisala kar Busheva sama.

Članek analizira načine prenašanja in adaptacije idej iz izvirnih književnih del v popularne pesmi. Glasbenike tako predstavlja ne zgolj kot inovativne ustvarjalce novih umetniških del, temveč tudi kot tvorce adaptiranih umetniških del, ki jih lahko medbesedilno beremo v kontekstu kulturne dediščine avtorjev književnih del.

Ključne besede: popularna kultura; rock glasba; književnost; adaptacija 


\section{In Between the 'Brows': The Influx of Highbrow Literature into Popular Music}

\section{Defining the Brows}

One of the most interesting phenomena in popular music since the middle of the twentieth century has been the merging of what had traditionally been deemed high and low culture. After the affirmation of popular culture as culture in the first place, popular singers and songwriters started including in their songs references to literary works traditionally thought of as belonging to highbrow literature, that is to say, what had once been thought of as the domain of a minority of well-educated, wealthy readers now found its way into music of widespread popularity. High and low culture merged to form something accessible today to much of the world's population, through television, radio and, most recently, the internet.

This article proposes to look at several popular songs that make direct references to or were inspired by works from the Anglo-American literary canon. Before examining the adaptation of literature into music, I will first define a general framework by providing an overview of theoretical stances on popular culture in general, its coming into being, its relation to mainstream culture, and the terminology pertaining to different cultural strata. In the final section, I will look back on the development of the relation between the centre and the margin as seen in different subgenres of popular music.

\subsection{Introduction}

“...rock 'n' roll appeared, not only as music, but also, I would say, as a life attitude that unleashes inside man those things that Western civilization dressage stifles all the time: the right to pure emotion, to the exchange of unmanipulated existential energy, the right to not conform." (Pantić 2005, 12)

The adaptation of literature to music means transposing a text from one medium to another. Indeed, if postmodern playfulness means something, then it is precisely the constant remaking and adapting of an existing text into a different art form: literature to film, film to literature, literature to opera, ballet and musicals, literature to comic books, comic books to film. The combinations and possibilities of variation seem limitless; additionally, we may include the practice of merely alluding to a pre-existing text in a loose manner, for instance, by inserting the words "based on" in the opening of a film, or of restricting the domain of the adaptation to allusion and intertextual play, as is sometimes done in musical texts.

To what extent is a new work of art allowed to change the original and yet still be considered an adaptation of another work of art? Linda Hutcheon distinguishes between what is and what is not adaptation: adaptations might be "films and stage productions, but also musical arrangements and song covers, visual art revisitations of prior works and comic book versions of history, poems put to music and remakes of films, and videogames and interactive art", but "allusions to and brief echoes of other works would not qualify as extended engagements" of an already existing work (Hutcheon 2006, 9). What does this mean in the context of studying the "highbrow" literature that found its way into the lyrics of popular music? Are we even prepared to consider these lyrics as adaptations in the way that we accept Peter Jackson's Lord of the Rings as an adaptation of J.R.R. Tolkien's novel, or, are we in fact talking about an utterly different 
form of expression, something other than adaptation, when we consider literature in music?

Let us take adaptation of this kind a step further (or back?) and consider it a (mere) intertextual referencing, or, in other words, let us try to view the accidental or intentional usages of literature in popular music as a natural act in the process of music's creation. If we think of it in this spirit, can we not say that we are, as individuals and as artists, all immersed in the literature that formed Western civilization? Intertextuality, one of the credos of contemporary literary theory, is the concept that never is the text "an individual, isolated object but, rather, a compilation of cultural textuality" (Allen 2000, 36); this puts us in a position where every text produced is to be viewed through the net of all the texts written before it. Any text is already in itself a palimpsest, and as with all palimpsests the underlying layer is visible on the new surface, that is, inside the lines of the newly written. Contemporary theory, writes John Fiske, has unanimously accepted that no text is complete, and that we can only read a text as belonging to and encompassing all other texts; that is, we can only read a text intertextually (Fiske 2001, 143). Every text is created and repeated in a constant dialogue with all other texts, because both the creator and the receptor of that text already carry the "luggage" of pre-existing texts. Therefore, a writer of lyrics is always writing and singing the words, with all the other words of his or her cultural heritage vocalizing or humming in the background. How considerable, then, is intent when alluding to or paraphrasing a poem? Moreover, how receptive is the audience of this adaptation? This depends every time on the artist writing and performing the music - his or her background, education, interests, musical and overall cultural influences - and on the audience for which the music is performed - their own background, education and so on. In this sense, we find ourselves in the situation of employing the biographical method for all artists, researching their own proximity to highbrow literature and analysing the ways in which they incorporate it into the lyrics. Here I will discuss several examples and consider how the original literary text was transposed and transformed into the musical lyrics. The focus will be on rock and alternative music, with artists whose artistic expressions were formed during the 1960s and 1970s in the English-speaking world.

\section{Culture and All Its Prefixes}

Definitions and clear boundaries are hard to set. The term culture is difficult enough to define: T.S. Eliot considered it "a word which nobody bothers to examine" (Eliot 1977, 86), which is why Eliot tried to do exactly that in his 1948 essay "Notes towards a Definition of Culture." Among several hypotheses, Eliot discusses, particularly in the first chapter, "Three Senses of 'Culture'," the scope of this term we so frequently (mis)use, and mentions that culture

may even be described simply as that which makes life worth living. It is what justifies other peoples and other generations in saying, when they contemplate the remains and the influence of an extinct civilisation, that it was worth while for that civilisation to have existed (Eliot 1997, 100).

Furthermore, Eliot demonstrates a few pages later just how comprehensive the term culture can be:

the reader must remind himself [...] of how much is here embraced by the term culture. It includes all the characteristic activities and interests of a people: Derby Day, Henley Regatta, Cowes, the twelfth of August, a cup final, the dog races, the pin table, the dart board, Wensleydale cheese, boiled cabbage cut into sections, beetroot in vinegar, nineteenth-century Gothic churches and the music of Elgar. The reader can make his own list" (Eliot 1977, 103-4). 
Including such cultural concepts as boiled cabbage and the dart board inside the term culture would have proved shocking for the more conservative, traditional theoreticians who lived and wrote before Eliot, notably Matthew Arnold, who in the second half of the nineteenth century wrote a series of essays entitled Culture and Anarchy, equating, in a sense, culture with high culture, limiting Culture to a word spelled with a capital letter: "culture is, or ought to be, the study and pursuit of perfection; and that of perfection as pursued by culture, beauty and intelligence, or, in other words, sweetness and light, are the main characters" (Arnold [1869] 2001, par. 58). On the other hand, the masses, Arnold considers, are "so raw and uncultivated" (par. 62); but they have a chance to be cultivated through military service, which, in turn, would instill in them "the idea of public duty and of discipline" (par. 62). Arnold also agrees with his French peer Ernest Renan, when Renan says that, unlike in the United States, where education is wasted, as it were, on just anyone, any member of any given class, without distinction, in Britain "[t]he sound instruction of the people is an effect of the high culture of certain classes" (qtd. in Arnold, par.14); in the case of the United States, this undifferentiated "popular instruction" will result in, Renan says (and Arnold quotes and agrees), "intellectual mediocrity, their vulgarity of manners, their superficial spirit, their lack of general intelligence" (par. 14).

Arnold's text was written and published in the 1860s; what has changed so radically in the last one hundred and fifty years that today by culture we have come to mean, among other things, graphic representations of differently-coloured cans of tomato soup? Can Madonna's shocking stage performances of the 1980s, complete with fishnet-stockings, be viewed as culture alongside, say, Thoreau or Emerson? When did culture lose its capital first letter, and become writeable in the hand of any plebeian?

Thoreau and Emerson would be here encompassed by the term highbrow culture, while Madonna with her fishnet stockings and Andy Warhol with his tomato-soup cans would once have been considered lowbrow culture. The term highbrow, according to the Oxford English Dictionary, was first used in print as an adjective in 1884; the noun highbrow stands for "[a] person of superior intellectual attainments or interests: occas[ionally] with derisive implication of conscious superiority to ordinary human standards." Art enjoyed by this social strata would, thus, be considered highbrow art, difficult to understand by the lowbrow social strata, meaning those with inferior intellectual attainments or interests.

Other terms that are frequently used to differentiate between the different levels in culture are high or elite culture as opposed to low; then there is the term of counterculture, a phenomenon that appeared in the United States in the 1950s, brought about by the newfound social and economic status of young people who started forming tastes and opinions of their own and expressing them freely; in this same sense, we now use the term youth culture. Terms such as subculture, popular/pop culture and mass culture are usually used to represent those cultural streams standing opposite, under or against the high, elite, classical, canonized culture and the values it promotes, and these streams were for a long time considered lower in quality.

In defining the differences between the mainstream, the accepted cultural values and all that stands on its margins, Pierre Bourdieu claims that one of the most important differences between high and popular culture is that popular culture erases all borders between aesthetics and everyday life (qtd. in Fisk 2001, 147). Bourdieu further argues that the difference between, say, a bourgeois, middle-class party and a working-class football match or circus show is in the participation of the audience. While the middle-class party means keeping one's distance, the working-class shows involve taking an active part in what happens on the stage/field by shouting, whistling, loudly 
commenting or even joining in the match. The distance kept during, for example, a concert of classical music is twofold: it is both the distance kept by the audience in relation to the work of art and the distance that the work of art has in relation to everyday life, to the banality of the quotidian. This distance, says Bourdieu, is a distance kept out of respect and admiration for art, and it denies that art has any kind of quotidian or material purpose. Popular culture, on the other hand, reads and understands art as an integral part of the quotidian, therefore denying it a separate and privileged position outside of everyday life. By shouting and whistling at a rugby match or coming onto the stage during a play or a rock concert, consumers of popular culture take a direct part in the art they admire, and even identify more fully with the object of admiration.

This brings us to Mikhail Bakhtin's concept of the carnivalesque: the Middle Ages and Renaissance tradition of carnivals, Bakhtin tells us, did not know of such a concept as the border between performers and audience. The carnivalesque practices knew nothing of the distance mentioned above: the carnival was to be lived and lived in, as opposed to merely watched; furthermore, it was something everybody lived in regardless of class, gender, or age. The character of the carnival was popular, all-encompassing (Bahtin 1978, 13-14), and it was an artistic happening everybody created and represented at the same time, whereas observing a work of art from a distance, like at a classical music concert, presupposes a border between audience and performers that the carnival erases.

Another important marker of the carnivalesque state and behaviour is the annihilation of social roles: during carnivals, the officials of a town's administration, the bourgeoisie, and anyone, for that matter, considered to have a high standing role within society becomes his or her peers' equal. The same can be said of a rock music concert: any kind of political, economic, gender or other social denominator becomes unimportant.

Therefore, rock 'n' roll culture, in the mid-twentieth century, created a bridge that made the two brows finally meet on the global cultural forehead, by performing for the masses, adopting all the aspects of the carnivalesque, all the labels of the popular, and yet, at the same time, showing a close connection to the artistic and cultural history preceding it.

A good example is the famous Stones in the Park concert on the fifth of July 1969, held in London's Hyde Park, only a couple of days after the death of the guitarist Brian Jones, the concert itself becoming a memorial to Jones; to begin the concert and honour the memory of their friend, Mick Jagger famously performed an excerpt from Shelley's Adonaïs onstage, thus offering the tribute that Shelley offered to the memory of Keats to the departed Jones. The parallel between the two close friendships, Shelley-Keats and Jagger-Jones, harbours more than a mere allusion and more than a mere spectacle for the audience gathered in Hyde Park on that summer day. It presents Jagger in a different light: Jagger, the buffoon, problematic, long-haired frontman of a rock band demonstrated his knowledge of English literature - in poetry, no less. By bringing onto the stage with him Keats and Shelley, the respected and uncontestable representatives of high culture, Jagger claimed a position within the cultivated stratum of Britain's artists. He proved himself not just a walking, screaming rebel, but a well-read rebel.

How did the former image of rock musicians as uncultivated destroyers of tradition come to be formed in the first place, and how did they manage to deconstruct it and create a place for themselves, creating a connection to their artistic predecessors and influences? 
After two World Wars, the cultural heritage that the older generations could offer was gone. Europe as the centre of humanism, of fine arts and reason, was a concept badly shaken by World War I (and so finely represented in the works of the modernists and their cries for a world long gone), and tragically confirmed by the devastating images and sounds of World War II. In such a climate, the 1950 s brought about a feeling of estrangement between the old and the young generations. Not that this difference in sensibility, interests and character had not always existed, but never before had it been regarded as a phenomenon in its own right, and never before had the younger generation gone so far as to express, violently, this difference in their art. Dick Hebdige lists some of the conditions that brought about change in society and culture after World War II: for one, young people now had jobs and their own money to spend, and, consequently, more financial and intellectual independence, more free time to form and express their own attitudes (Hebdige 1980, 78).

Among other things, this meant that young people now had a chance to decide about their own taste in art. The 1950s in Britain and in the United States saw the appearance of rebels without causes in all art forms: James Dean as the young and aggressive icon standing up to the moral values of his parents soon became the model for an entire generation. This generation now made a sharp turn in their art, fashion, political opinions and lifestyles. In music, in the early and mid-1960s, the British bands The Beatles, The Who, the Rolling Stones and others moved westwards, to perform what is known today as the British Invasion of the American market and the American musical scene.

Moreover, in the emerging rock music of the sixties, the mutual influences of artists with different artistic expressions could already be seen. The Beatles spelled their name with an 'a' as a reference to the Beat generation of poets by whom they were influenced. The Beatniks, Allen Ginsberg, Jack Kerouac and others, befriended Lennon and McCartney, as well as Bob Dylan and the Rolling Stones, and many other representatives of the generation of performers that marked the very basis of rock 'n' roll culture. Their mutual influence cannot be denied, and traces of it are many: they formed part of the same ideological movement of rebellion, but found their expression in different art forms. Bob Dylan made records, but also produced books of poems and drawings; Leonard Cohen has a musical as well as a notable literary career; the same could be said of the works of Jim Morrison.

After the 1960s, the subgenres of rock music started to diverge, so that by the second decade of the twenty-first century, we listen to genres as different as gangsta rap and dubstep, triphop and death metal, and so on. All of these, however, stemmed from this one source in time and space, later being combined with local or national styles, advancing with technology and fusing techniques and diverse orchestration to form the many genres of the present. They all stemmed from a counter-movement, a rebellion against accepted post-World War II, middle-class philosophy. In this rebellion, artists often, consciously, looked back to the rebels of the past, mixing tradition with their individual talent in order to form something post-modernly new. Who are the sources they drew from? Are they identifiable? Or, better yet, are they as easily identifiable today as they were, say, in the 1950s and 1960s, where we can trace, for instance, William Blake's influence on the poetry of Allen Ginsberg on Patti Smith - or, for that matter, the influence of Arthur Rimbaud on Patti Smith, and Patti Smith's own influence on The Smiths or U2?'

When writing about the punk movement in Britain in the seventies, Hebdige notes an "implicit

"You see, I had devoted so much of my girlish daydreams to Rimbaud. Rimbaud was like my boyfriend" (Moore, par. 14) 
connection" between these young working-class anarchists and high forms of literature like art and film (1980, 37); the connection is seen in the icons and predecessors of punk, including David Bowie and Patti Smith, who came from the ranks of well-read artists who knew how to quote their favourite writers by heart. The implicit predecessors of the punk movement in Britain, then, had been - by way of the New York scene (the Velvet Underground, etc.) - also the French symbolists.

\subsection{The Rolling Stones of Inspiration}

"- When those lines make their way into a song, you're conscious of it happening?

- Well, not really. But even if you are, you let it go. I'm not going to limit what I can

say. I have to be true to the song." (Bob Dylan in Gilmore 2012, 7)

Rock music has drawn inspiration from various literary genres: poetry, which has been adapted to music directly, meaning entire poems have been sung to melody; but also fiction, where we find excerpts from prose also sung to melody, or symbols, characters and situations adapted for music, or songs structured around them.

Some artists drew inspiration from their literary influences for their stage names or the names of their bands: Bob Dylan (from the poet Dylan Thomas); Steppenwolf (from Herman Hesse's novel); The Velvet Underground (from Michael Leigh's novel of the same title); Moloko (taking its name after Burgess' A Clockwork Orange and the word for "milk" in the Slavic-sounding argot spoken by the characters in the book). Examples are numerous, and the habit or fashion of drawing inspiration from literary sources does not seem to have abated over time (more recent examples of band names such as As I Lay Dying, Of Mice \& Men, The Dangerous Summer confirm the rule).

There are bands and performers that have, throughout their careers, become known specifically for incorporating literary works into their lyrics. An interesting point could be made, however, about the songs' authors: it is undeniable that a certain unconscious intertextuality always exists and that, whoever the author of the text, he or she writes lyrics that are, even before they are written down, pregnant with the meanings ascribed to those words by a particular language and particular culture. We should bear in mind, however, that not all authors of all texts that end up as lyrics for popular songs necessarily know the impregnated value of those words. We can, however, assume this in the case of Sting, for instance, writing the lyrics for the 1980 "Don't Stand So Close to Me":

It's no use, he sees her

He starts to shake and cough

Just like the old man in

That book by Nabokov

Sting used to work as an English teacher, and if the subject of the lyrics does not make it clear enough that the song is about a fatal attraction between an older teacher and his student akin to that seen in Lolita, Sting makes it clear by alluding to Nabokov in name. "Sister Moon", another Sting hit, takes a line from Shakespeare's Sonnet 130: "My mistress' eyes are nothing like the sun" (even the entire album is entitled ... Nothing Like the Sun, stemming from the same sonnet). 
Other examples are easy to find; in Sting's 1985 "Consider Me Gone," the lyrics of Shakespeare's Sonnet 35 are taken almost word for word. Sting says:

Roses have thorns, and shining waters mud

And cancer lurks deep in the sweetest bud

Clouds and eclipses stain the moon and the sun

Shakespeare's Sonnet 35 contains almost identical lines:

Roses have thorns, and silver fountains mud,

Clouds and eclipses stain both moon and sun,

And loathsome canker lives in sweetest bud.

Iron Maiden, a band associated with the beginning of the musical genre of heavy metal, has, since the mid-seventies, drawn inspiration for their lyrics from various literary genres, epochs and styles. Some of their more famous songs include clear literary references even in name: "Lord of the Flies," "Murders in the Rue Morgue," "The Phantom of the Opera," "Rhyme of the Ancient Mariner," "Brave New World," and "To Tame a Land." Their "Rhyme of the Ancient Mariner" is a thirteen-and-a-half-minute song quoting parts of Coleridge's poem directly.

The British band The Cure, formed in the late 1970s (with Robert Smith as frontman and the main author of the lyrics), and belonging to a genre labelled gothic rock, is famous for including allusions to literary works in their songs and drawing inspiration from literature. When asked about the greatest influences on his music and lyrics, Smith has quoted Camus, Sartre and Kafka (Smith 1990, par. 54). For instance, "Killing an Arab" (1979) is not only a textual allusion to Camus' The Stranger, a novel about the killing of an Arab man, it resonates with the same atmosphere of existential desperation in the face of a Sisyphean, hot, stifling world on a heavy afternoon:

I can turn

And walk away

Or I can fire the gun.

Staring at the sky.

Staring at the sun.

Whichever I chose,

It amounts to the same:

Absolutely nothing.

The Cure's discography includes songs like "Adonais," based on Shelley's elegy; the song "Bananafish Bones" was based J.D. Salinger's short story "A Perfect Day for Bananafish." "Treasure" from the 1996 album Wild Mood Swings loosely quotes the poem "Remember" by Christina Rossetti. As in "Killing an Arab," the lyrics, combined with an already formed, recognizable Cure mood, produce an atmosphere similar to that of Rossetti's poem: 
'Please remember me

When I am gone from here'

She whispers

'Please remember me

But not with tears.

Remember I was always true

Remember that I always tried

Remember I loved only you

Remember me and smile

For it's better to forget

Than to remember me

And cry

Rossetti's poem has the same topic: the sadness of the lover in the face of death that is yet to come, the wish that the loved one would remember him or her without sadness, or, if that be the case:

Yet if you should forget me for a while

And afterwards remember, do not grieve:

For if the darkness and corruption leave

A vestige of the thoughts that once I had

Better by far you should forget and smile

Than that you should remember and be sad.

Another British band, The Smiths, are well-known for taking many of their lyrics directly from literary works: in the song "Handsome Devil," the line "there is more in life than what you read in books" comes from Vonnegut's Slaughterhouse 5. The Smiths, and their frontman Morrissey in his solo career that started at the end of the 1980s, wrote songs with titles taken from books or lines from books: "Shakespeare's Sister," "Everybody's Clever Nowadays" (from Oscar Wilde's The Importance Of Being Earnest), "Pretty Girls Make Graves" (Jack Kerouac's Dharma Bums), as well as such obvious references as "Billy Budd" and "King Lear."

Many performers with literary connections in their lyrics could be enumerated here, stressing the fact that these bands belong to different genres and different epochs: "Don't Look Back in Anger" by Oasis (from John Osborne's play); Crash Test Dummies: "Afternoons and Coffeespoons" (alluding to the famous words from "The Love Song of J. Alfred Prufrock"); Pink Floyd: "Animals" (based on Orwell's Animal Farm); Muse: "Resistance" (inspired by the love story in Orwell's 1984); The Divine Comedy: "Lucy" (William Wordsworth's Lucy poems); The Ramones: "Pet Sematary" (from Stephen King's eponymous novel); Bob Dylan's "Ballad of a Thin Man" (inspired by J.D. Salinger); Patti Smith's "Footnote to Howl"; Nick Cave mentions Nabokov, Philip Larkin, Dylan Thomas and others in "There She Goes My Beautiful World." In "Rave On John Donne," Van Morrison invokes the names of Donne, Yeats, Whitman, Khalil Gibran and Omar Khayyam, all revolutionary poets in their own time. 
Perhaps one of the most well-known examples of brow elevation is British singer Kate Bush's 1989 single "The Sensual World," in which Bush originally intended to quote exactly from the soliloquy of Molly Bloom in James Joyce's Ulysses. However, since the Joyce Estate refused to grant permission, the song was recorded with lyrics that Bush wrote herself, inspired by Molly Bloom's words. In 2011, however, Bush finally obtained permission and re-recorded the song, now under the title "Flower of the Mountain" on her 2011 album Director's Cut (even the title of the song is a direct quote from the famous novel).

"Flower of the Mountain" quotes Molly Bloom's soliloquy exactly, adding the words "stepping out off the page into the sensual world" - Bush's addition, or, better said, a sort of directorial didascaly, pointing to the fact that this character, realized in the novel through this last chapter narrated in the style of internal monologue, now steps off the page and into the sensual world that her own words describe. Accordingly, in the 2011 music video, two ballet dancers, a male and a female, perform a sensual, passionate dance, bringing to life the story Molly recounts in her monologue about her love for Leopold Bloom.

\subsection{The Rock Poets}

By far the most interesting writers of lyrics to analyse are those who themselves have a recognized literary standing. For a long time their literary standing was disputed by some academics. These rock-poets were seen as musicians primarily, as entertainers, and thus did not have a place in the canon of British and American literary tradition. They remained, for a long time, only rock 'n' roll icons, but they were not accorded the status of, say, a Thoreau, Whitman or a Pound. Nevertheless, poets like Bob Dylan, John Lennon, Leonard Cohen or Jim Morrison can now be studied together with the literary influence that shaped them and that is the context within which we should read their works. Like other artists, they drew from tradition and added to it their individual talent, sometimes combining it with music, and sometimes writing and publishing their own verses and collections.

Leonard Cohen took the lyrics for his hit "Take This Waltz" from Federico Garcia Lorca's poem, which Cohen himself translated into English and then adapted to music. "Pequeño Vals Vienes" is Lorca's elegy for lost love, and Cohen translated this longing into English and sang it to his own music. Cohen was known as a poet and novelist even before becoming directly involved in music, publishing extensively, although his success was not on a great scale, certainly not on the scale of his later musical career. The lyrics for his greatest hits, therefore, are heavily influenced by the formative influences on his poetry and fiction. Cohen has come to be known as an artist who feels comfortable expressing himself in various artistic forms.

Another multi-talented artist, very diversified and eclectic in his artistic expression, who marked the second half of the twentieth century, is David Bowie. Bowie is well-known for his experimentation with genres and styles; he wrote a series of songs inspired by Orwell's 1984, which he meant to put together into a musical (encountering copyright issues, just like Kate Bush, Bowie was forced to give up on the idea of a musical, but still used 1984 as inspiration for the 1974 album Diamond Dogs: two of the tracks on the album are "1984" and "Big Brother"). Examples of Bowie's interest in literature and the inspiration he has drawn from it are numerous. In the 1970 "The Man Who Sold the World," for instance, Bowie quotes from the poem "Antigonish" by Hughes Mearns; Mearns' poem starts with "Yesterday, upon the stair, / I met a 
man who wasn't there," while Bowie's song (later, in turn, famously re-interpreted by the grunge band Nirvana, to become one of their greatest hits) reads: "We passed upon the stair, we spoke of was and when / Although I wasn't there, he said I was his friend."

Bob Dylan's stage name itself is a literary intertextual game: it is a variation of the name of Dylan Thomas, the poet. Surely Dylan (having written this song in 1965) was closely connected in topic and tone to the Beat generation of poets and the literary movement at whose forefront stood Jack Kerouac, with his novel about this generation, On the Road: the atmosphere of that novel, the atmosphere of Ginsberg's poetry and Bob Dylan's "Like a Rolling Stone" all portray the same feelings of desolation and disappointment at the world that once promised so much; they all convey the will to free themselves of social norms, including their worldly possessions; for, what is a rolling stone if not a stone free to roll away wherever it wants?

Another intertextual play is the name of the California band The Doors, which drew its name from William Blake's verses in The Marriage of Heaven and Hell, by way of Aldous Huxley's Doors of Perception:

For man has closed himself up, till he sees all things

thro' narrow chinks of his cavern

If the doors of perception were cleansed every thing

would appear to man as it is, infinite.

The band's frontman, its icon and a guru in rock culture, was Jim Morrison, another twentieth century rock poet. How much Morrison followed Blake as one of his masters we can see in the overall idea of cleansing the doors of perception that humanity has temporarily sealed but which can be opened up once again. Jim Morrison has been analyzed as an amalgam of literary influences. Indeed, as a student of literature and film at UCLA, Morrison read Nietzsche, Blake, Antonin Artaud and Rimbaud. French symbolism influenced his vision of the modern city as a place that "offers art and life as well as an ominous source of disease and death" (see Cook, par. 25). In the song "LA Woman," for instance, the Doors sing of an all-pervading loneliness and estrangement in big cities, a common topic among postmodern artists. The era Morrison sings about is an era of quest, a limbo between the old values that are no longer held sacred, and new ones that fail to deliver a message of hope; as Kennedy writes in Strange Brew: Metaphors of Magic and Science in Rock Music, it was "a time of change and desire for improvement, hopes for freedom and excitement at the failure of old leaders and institutions were tempered with fears of betrayal by the new ones" (Kennedy 2013, 88-89).

Morrison included other famous Blake quotations in his songs. For example, "End of the Night" is a direct rendering of Blake's "Auguries of Innocence": "Some are born to sweet delight. / Some are born to the endless night." In Blake's long poem (Morrison directly quotes only the very ending of it), Blake is concerned, as in much of his writing, with primarily two sets of opposites. The first is that of innocence and faith on one side and cruelty and doubt on the other:

He who mocks the Infant's Faith

Shall be mock'd in Age \& Death. 
He who shall teach the Child to Doubt

The rotting Grave shall ne'er get out.

The other opposition that Blake wrote about and by which Morrison was heavily influenced, was that of individual perception on the one and collective reality on the other side; Blake says:

God Appears \& God is Light

To those poor Souls who dwell in the Night,

But does a Human Form Display

To those who Dwell in Realms of day. (Blake 2000, 139)

Much of Morrison's writing, both in the lyrics for The Doors and in his poems, was concerned with these oppositions, especially pertaining to the American social and political situation of the sixties. More than Blake, however, Morrison experimented with the doors of his own perception and, considering himself a poet-shaman and relying heavily on Native American tradition, he, as one author notes, lived his life "romantically drawing on Blake's dictum that 'the road of excess leads to the palace of wisdom" (Cook 2013, par. 77); or, we might say, "You never know what is enough unless you know what is more than enough" (Blake 199). Like Blake in his own time, Morrison felt the corruption of modern society, the drifting away from nature, the consumerist craze building up, and this is clear in his poetry collection Wilderness (1988) about a certain "vanity of the senses" that makes the contemporary world unbearable to live in:

Old men worship w/long

noses, old soulful eyes.

Young girls worship,

exotic, indian, w/robes

who make us feel foolish

for acting w/our eyes.

Lost in the vanity of the senses

which got us where we are.

(Morrison, no title, segment: "The Anatomy of Rock")

\subsection{Case Study}

Sometimes, in these times of musical mass production, the accepted wisdom seems to be that a quotation from a well-known literary work will somehow give seriousness to otherwise lowquality music and connect it to works of highbrow culture. This is how producers tried to give a literary, cultural feel to pop singer Cheryl Cole's 2012 dance hit "Call My Name," by inserting at the beginning of the video a quote from the Marquis De Sade. "The only way to a woman's heart is along the path of torment" reads the image, as the singer walks along an abandoned concrete construction towards a group of men; she is wearing high heels, a revealing top and heavy make-up. The parallel between the video and the quotation from De Sade is not clear: this is not a woman who is tortured by men in the video; her only contact with the group 
of males seems amicable and, although openly sexual, not abusive on either side. The sexual connection is obvious, yet the video is not provocative enough to bring to mind De Sade's work - if indeed this was the idea of the video producers. Cole (or, more likely, the producer of her video) is legitimately entitled to use De Sade as a reference: it is part of their cultural inheritance as much as it is of any other artist rooted in Western history of art. Yet, one wonders what the connection could possibly be. We remember that De Sade was not warmly received in his own time, that he was imprisoned, his works banned, and that he remains one of the most controversial personalities in history, while in literary studies his works still provoke readings of completely opposing natures (he is seen both as a radical liberal who frees women and as a radical chauvinist and woman-hater, for instance); we can also remember that he was a direct inspiration for such landmark films as Buñuel's The Golden Age and Pasolini's Salò. Those films also proved to be bones of contention among critics and spectators for their content and expression. On the other hand, Cheryl Cole is a well-received mainstream artist, singing mainstream pop music and not associated with anything remotely scandalous in her work, there is no pattern of rejection from her peers or the audience. The only connection, it seems, is sexuality, and yet even that is represented in two completely different if not opposing ways in the pop song and the literary work. In this case, the attempt to attain relevance through intertextuality backfires.

\title{
3 Conclusions: Creative Disobedience, Dead or Alive?
}

\begin{abstract}
"Perhaps we should not write about rock 'n' roll at all? It would probably be better to simply listen to examples, nod our heads in the rhythm of the songs and tap our feet against the squeaky parquet." (David Albahari)
\end{abstract}

Fiske, in Understanding Popular Culture, makes an argument concerning populism and left-wing politics by mentioning the song "Beds are Burning" by the Australian band Midnight Oil. The song, Fiske contends, has a clearly pro-Aboriginal message in the lyrics in connection to the taking of Aboriginal land in Australia by the white settlers, a wrong perpetuated to this day:

The time has come
To say fair's fair
To pay the rent
To pay our share
The time has come
A fact's a fact
It belongs to them
Let's give it back

However, the song is popular among the traditionally racist miners in the Australian bush, who may represent the racist politics of the big oil companies that employ them (Fisk 192). Such listeners only pay attention to the hard rock melody, and not to the obviously left-wing lyrics, says Fiske.

Fiske also writes about the reception of the TV show Dallas. In terms of popular culture, Fiske says, we can read a critique of patriarchy and capitalism in Dallas, but this does not mean that 
all the viewers of Dallas will necessarily interpret the show in this way. They are just as likely to read it from the standpoint of the sexism, racism, or capitalist values which exist in the show, since, Fiske says, these are present in the society that produced it (2001, 54-55). We can regard the influx of highbrow literature into popular music in the same manner: if Kate Bush sings the lyrics from Molly Bloom's soliloquy in "Flower of the Mountain," not many of her thousands of listeners will know where the lyrics come from, nor will they be familiar with the context, Molly Bloom's character, the situation leading to her soliloquy, not even the fact that the original version of the song was called "The Sensual World" and that it carried significance for the character of Molly Bloom, for she, as the song says is "stepping out of the page into the sensual world." Therefore, how much could we say is preserved from the intent of the original text when this text is sung to melody, the intent of the original text often being highly subversive, even revolutionary? Coming back to theory of adaptation, we could ask this question about any kind of adaptation, even that of the most frequent kind, literature to film: how faithful does the adaptation remain to the primary intent of the original?

We can regard this change in the subversive message as yet another instrument of mainstream culture. Eventually, through the media, society manages to equalize what was once regarded as deviant, contra- and sub- so that it becomes, as Hebdige says, a mere spectacle inside the overall accepted societal mythology that, in part, had produced the subcultural movement in the first place (cf. Hebdige 1980, 95). The point in time where music meets marketing and business strategies marks the moment of punk's death, that is, the moment where creative disobedience starts being gradually reduced (back) to its carnival practices (Ilić 2013, 200-201). The Other is tamed, the uncontrollable masses tranquilized and time is again back in its joint. Fiske quotes Terry Eagleton in saying that the governing structures permit carnival (read: lowbrow) practices to enter the mainstream, to be encompassed there, all in order to control the masses more easily (Fisk 2001, 117). On the other hand, Roland Barthes believed that radical changes provoked by popular culture never take place on the macro level at all, but rather on the micro level of society; avant-garde art, according to Barthes, does not challenge the economic or political power of the bourgeoisie, but only the ethical and aesthetic principles built on them (qtd. in Fisk 2001, 220). ${ }^{2}$

However, if we follow Hebdige's line of thought, we can observe that, from a countercultural movement, The Doors, for instance, found their way into or were, conversely, encompassed by mainstream culture, reaching a far greater number of people, consequently making songs such as "Light My Fire" into global hits to be hummed by various generations, played on juke-boxes, in elevators and supermarkets. Morrison's lyrics are a cry for waking up, for breaking through to the other side of things and the material world, but, at the same time they are also a mere tune to which the masses dance without thinking about meaning in the words. How much do we think about Morrison's message, and how much do we merely enjoy the hip-swinging rhythm brought into our everyday lives by the ever-present commercialized music industry? This question could well be a topic for further detailed research conducted by scholars who recognize the intertextual plays and influences of the literary tradition on writers of rock 'n' roll lyrics. It would also involve the study

Editor's note: There were parallel brow-raising efforts on the musical side of the songs. For example, George Martin's string quartet arrangement for The Beatles' "Eleanor Rigby” on Revolver (1968) and Robby Krieger of The Doors incorporating the first section of Isaac Albaniz's Asturias (Leyenda) in "Spanish Caravan" (1968). In the prog-rock genre, Keith Emerson of The Nice recorded "Intermezzo from the Karelia Suite" (Sibelius) on Ars Longa Vita Brevis (1968); Yes recorded "Cans and Brahms," Rick Wakeman's adaptation of the third movement of Symphony No. 4 in E minor by Johannes Brahms on the album Fragile (1971), and Keith Emerson of Emerson, Lake and Palmer recorded Aaron Copeland's Fanfare for the Common Man (1978). The practice continues today as artists sample sections of classic rock recordings and incorporate them into their works. 
of the different ways in which we perceive literary texts, on the one hand, and lyrics sung to music, on the other. The processes for understanding the message of Blake's Marriage of Heaven and Hell, as opposed to dancing to the sound of "People are Strange," for instance, are certainly different.

What does remain certain and what has been recognized even within the highbrow reaches of academia is that writers of rock 'n' roll lyrics are inheritors of a cultural history in their own right, and that their re-reading and re-interpreting of the literary canon will bring further insights into texts deemed all but read-through.

\section{References}

Allen, Graham. 2000. Intertextuality. London: Routledge.

Arnold, Matthew. 2001. Culture and Anarchy. Project Gutenberg. http://www.gutenberg.org/ebooks/4212.

Bakhtin, Mikhail. 1978. Stvaralaštvo Fransoa Rablea i narodna kultura Srednjeg veka i Renesanse. Beograd: Nolit.

Blake, William. 2000. The Selected Poems of William Blake. Hertfordshire: Wordsworth Editions.

Cook, William. 2012. “Jim Morrison's Poetry: A Critical Analysis.” William Cook - Jim Morrison's Poetry. http://jimmorrisonspoetry.blogspot.co.nz/.

Eliot, T. S. 1977. "Notes towards a Definition of Culture." In Christianity and Culture, 79-187. San Diego: Harcourt Brace \& Company.

Fisk, John. 2001. Popularna kultura. Beograd: Clio.

Gilmore, Mikal. 2012. "Bob Dylan Unleashed: A Wild Ride on His New LP and Striking Back at Critics." Rolling Stone Magazine, November 15.

Hebdige, Dick. 1980. Potkultura: Značenje stila. Beograd: Rad.

Hutcheon. Linda. 2006. A Theory of Adaptation. New York: Routledge.

Ilić, Boris. 2013. "Status rok subkulture u kulturnoj istoriji XX veka”. Koraci 1-3: 186-201.

Kennedy, Victor. 2013. Strange Brew: Metaphors of Magic and Science in Rock Music. Newcastle upon Tyne: Cambridge Scholars Publishing.

Moore, Thurston. 1996. “Interview with Patti Smith.” Bomb Magazine 54. http://bombmagazine.org/ article/1928/patti-smith.

Pantić, Mihajlo. 2005. “Conversation with David Albahari.” Gradac 156: 31.

Smith, Robert. 1990. "Interview for The Cure fanzine." Picturesofyou.us. 